\title{
Interaction between pro-inflammatory and anti-inflammatory cytokines in insulin-producing cells
}

\author{
Kleber L A Souza ${ }^{1,2, *}$, Ewa Gurgul-Convey ${ }^{1, *}$, Matthias Elsner ${ }^{1}$ and Sigurd Lenzen ${ }^{1}$ \\ ${ }^{1}$ Hannover Medical School, Institute of Clinical Biochemistry, 30625 Hannover, Germany \\ ${ }^{2}$ Department of Cell Biology and Genetics, University of Maringá, 87020-900 Maringá, Brazil \\ (Correspondence should be addressed to E Gurgul-Convey; Email: Gurgul-Convey.Ewa@mh_hannover.de) \\ (Present address of K L A Souza is the Department of Physiology and Biophysics, University of Campinas, Brazil) \\ *(K L A Souza and E Gurgul-Convey equally contributed to this work)
}

\begin{abstract}
Pro-inflammatory cytokines cause $\beta$-cell dysfunction and death. The aim of this study was to investigate the interactions between different pro- and anti-inflammatory cytokines and their effects on apoptotic $\beta$-cell death pathways. Insulin-producing RINm5F cells were exposed to different combinations of cytokines. Gene expression analyses of manganese superoxide dismutase (MnSOD) and inducible nitric oxide synthase (iNOS) were performed by real-time RT-PCR. Cell viability was measured by the MTT assay, $\mathrm{NFKB}$ activation using a SEAP reporter gene assay, protein expression by western blotting and caspase- 3 activity using the DEVD cleavage method. IL- $1 \beta$, tumour necrosis factor $\alpha$ $(\mathrm{TNF} \alpha)$ and a combination of all three pro-inflammatory cytokines increased while IFN $\gamma$ alone did not affect NFKB activity and iNOS gene and protein expression. Interestingly, the anti-inflammatory cytokines IL-4, IL-13 and IL-10 decreased IL-1 $\beta$-stimulated NFKB activation and iNOS
\end{abstract}

expression. IL-1 $\beta, \mathrm{TNF} \alpha$ and the pro-inflammatory cytokine combination also increased MnSOD gene and protein expression. But IL-4, IL-13 and IL-10 did not affect MnSOD expression and did not modulate IL-1 $\beta$-stimulated MnSOD expression. Caspase-3 activity was increased by IL-1 $\beta$ and the pro-inflammatory cytokine combination, and to a lesser extent by TNF $\alpha$. In contrast, IFN $\gamma$ had no effect on caspase- 3 activity. IL-4, IL-13 and IL-10 decreased caspase-3 activity and increased viability of insulin-producing cells treated with pro-inflammatory cytokines. The anti-inflammatory cytokines counteracted the cytotoxic effects of proinflammatory cytokines in insulin-producing cells. This was achieved through the reduction of nitrosative stress. Thus, a balance between the anti-inflammatory and the proinflammatory cytokines is of crucial importance for the prevention of pancreatic $\beta$-cell destruction.

Journal of Endocrinology (2008) 197, 139-150

\section{Introduction}

The pro-inflammatory cytokines, such as IL- $1 \beta$, tumour necrosis factor $\alpha(\mathrm{TNF} \alpha)$ and IFN $\gamma$, are putative mediators of the progressive loss of pancreatic $\beta$-cells in type 1 diabetes mellitus. These cytokines are released by macrophages and $\mathrm{T}$ cells in infiltrated islets of Langerhans and cause impaired function and ultimately cell death by apoptosis or necrosis (Eizirik \& Mandrup-Poulsen 2001). On the other hand, the release of anti-inflammatory cytokines, in particular IL-4, IL-13 and IL-10, is related to the protection of pancreatic $\beta$-cells (Zaccone et al. 1999, Kaminski et al. 2007) and the prevention of destructive insulitis (Rabinovitch \& Suarez-Pinzon 2003). Cytokines acting alone or in combination induce various transcription factors and signal transduction pathways within $\beta$-cells. One of the most important signalling events is the activation of the transcription factor, nuclear factor kappa B (NFKB; Eizirik et al. 1996b), which plays the role of a master switch in $\beta$-cells, activating transcription of a number of genes involved in cytokinemediated toxicity. Of great importance for cytokine toxicity in $\beta$-cells are in particular the generation of nitric oxide (NO) via induction of the inducible nitric oxide synthase (iNOS) and production of reactive oxygen species. Cytokine-induced nitrosative and oxidative stresses trigger eventually $\beta$-cell death (Eizirik et al. 1996a,b, Eizirik \& Mandrup-Poulsen 2001, Bast et al. 2002). $\beta$-Cells produce a large amount of NO when exposed to IL-1 $\beta$ or a combination of pro-inflammatory cytokines (Cetkovic-Cvrlje \& Eizirik 1994, Eizirik \& Leijerstam 1994, Eizirik et al. 1996b, Flodstrom et al. 1996, Darville \& Eizirik 1998). However, it is not clear whether NO is crucial for apoptosis in $\beta$-cells, since conflicting results have been published (Wright et al. 1999, Saldeen 2000, Zumsteg et al. 2000, Kuhn et al. 2003). The pro-inflammatory cytokines induce also the expression of manganese superoxide dismutase (MnSOD) in $\beta$-cells, the enzyme that resides in the mitochondria and generates there toxic hydrogen peroxide, which cannot be removed in face of lack of appropriate 
detoxifying enzymes such as catalase and glutathione peroxidase $(\mathrm{Gpx})$ in insulin-producing cells (Lenzen et al. 1996, Tiedge et al. 1997). The activation of MnSOD seems to play an important role in cytokine-mediated oxidative stress in $\beta$-cells (Lortz et al. 2005).

Although the action of anti-inflammatory cytokines has been studied in different cell types during recent years (Perretti et al. 1995, Berkman et al. 1996, Laffranchi \& Spinas 1996, Ledeboer et al. 2000, Lubberts et al. 2000, Nishisaka et al. 2001, Plunkett et al. 2001, Lieb et al. 2003, Serafin et al. 2004, Raz et al. 2005, Pennock \& Grencis 2006, Verri et al. 2006, Walsh 2006), little is known about the effects of these cytokines in pancreatic $\beta$-cells. It is known from the studies in different cell models that IL-4 is able to counteract many of the IL- $1 \beta$ effects, and reduced NO production has been considered an important element for this beneficial effect (Perretti et al. 1995, Ledeboer et al. 2000, Lubberts et al. 2000, Nishisaka et al. 2001). The biological effects of IL-13 may be achieved through binding to the IL-4 receptor$\alpha$ (Callard et al. 1996, Kotowicz et al. 1996, Kraich et al. 2006), and therefore it is generally assumed that these two cytokines overlap in the biological effects. The effects of IL-10 on the nitric oxide pathway are unclear and the opposite findings have been reported (Berkman et al. 1996, Laffranchi \& Spinas 1996, Plunkett et al. 2001, Lieb et al. 2003, Serafin et al. 2004). Some studies on anti-inflammatory cytokine action in insulinproducing cells have been published recently (Kaminski et al. 2007), but opposite effects with respect to $\beta$-cell survival have been reported and the underlying molecular mechanisms of the action of anti-inflammatory cytokines still remain unknown.

The pro-inflammatory cytokines may directly activate caspases, the main effectors of programmed cell death. Nuclear chromatin condensation and DNA fragmentation (classical characteristics of programmed cell death), sequential activation of caspases and segmentation in apoptotic bodies have already been described for insulin-producing cells exposed to cytokines (Delaney et al. 1997, Kurrer et al. 1997). Cell death by apoptosis is ultimately accomplished by effector caspases, i.e. caspases 3, 6 and 7 (Joshi \& Sahni 2003, Joshi et al. 2003). Previous studies have shown that TNF $\alpha$ activates caspases 3, 8 and 9 in different cell types (Alikhani et al. 2004) and that exposure of insulin-producing cells to IFN $\gamma$ causes activation of caspase-1 (Karlsen et al. 2000). IL-1 $\beta$ is able to activate caspase- 3 in $\beta$-cells and this effect is possibly linked to NO production (Chen et al. 2003, Veluthakal et al. 2004). However, also in this case, the differential effects of cytokines are unknown, and no data regarding the combined action of proand anti-inflammatory cytokines on caspase- 3 activation in insulin-producing cells are available.

Since cytokines may vary in their mechanisms of action, we decided to perform a detailed analysis of the effects of single pro- and anti-inflammatory cytokines as well as of different combinations, in order to analyse potential crosstalk. We studied the different pathways and mechanisms of pro-inflammatory cytokine-mediated $\beta$-cell death as well as their interactions with anti-inflammatory cytokines with particular emphasis upon the early changes in the death signalling pathways.

\section{Materials and Methods}

\section{Chemicals}

Cytokines and the dNTP mixture were obtained from PromoCell (Heidelberg, Germany). The jetPEI transfection reagent was purchased from Qbiogene (Heidelberg, Germany) and Biotherm Taq polymerase from GeneCraft (Münster, Germany). The SuperScript II RT reverse transcriptase and all tissue culture equipment were purchased from Invitrogen. All primers were from MWG-Biotech (Ebersberg, Germany). The Ac-DEVD-AMC caspase-3 substrate and Ac-DEVD$\mathrm{CHO}_{2}$ caspase-3 inhibitor were from Biosource International (Carnarillo, CA, USA). SNAP ( $S$-nitroso- $n$-acetylpenicillamine) was from Alexis Biochemicals (San Diego, CA, USA). Hybond $N$ nylon membranes, ECL detection system and autoradiography films were from Amersham Biosciences and Immobilon-P polyvinylidene difluoride (PVDF) membranes from Millipore (Bedford, MA, USA). All other reagents were from Sigma Chemicals (München, Germany).

\section{Cell culture and cytokine incubation}

Insulin-producing RINm5F cells were cultured as described (Lortz et al. 2000) in RPMI1640 medium, supplemented with $10 \mathrm{mM}$ glucose, $10 \%(\mathrm{v} / \mathrm{v})$ fetal calf serum (FCS), penicillin and streptomycin in a humidified atmosphere at $37^{\circ} \mathrm{C}$ and $5 \%$ $\mathrm{CO}_{2}$. For RNA extraction and protein analysis, cells were platted at a density of $2 \times 10^{6}$ per $90 \mathrm{~mm}$ plastic dish and grown to confluence within 2 days. Thereafter, cells were exposed to the desired concentration of pro- and/or anti-inflammatory cytokines, the nitric oxide-donor SNAP, the iNOS blocker $N \omega$-nitro-L-arginine (L-NOARG) and camptothecin. The concentrations of cytokines were $60 \mathrm{U} / \mathrm{ml}$ IL-1 $\beta$ $(4 \cdot 4 \mathrm{ng} / \mathrm{ml}) ; 600 \mathrm{U} / \mathrm{ml} \mathrm{IL}-1 \beta$ (44 ng/ml); $185 \mathrm{U} / \mathrm{ml} \mathrm{TNF} \alpha$ $(8.7 \mathrm{ng} / \mathrm{ml}) ; 1850 \mathrm{U} / \mathrm{ml}$ TNF $\alpha(87 \mathrm{ng} / \mathrm{ml}) ; 14 \mathrm{U} / \mathrm{ml} \mathrm{IFN} \gamma$ $(10 \cdot 3 \mathrm{ng} / \mathrm{ml}) ; 140 \mathrm{U} / \mathrm{ml} \mathrm{IFN \gamma}(103 \mathrm{ng} / \mathrm{ml}) ; 500 \mathrm{U} / \mathrm{ml}$ IL-4 (50 ng/ml); $500 \mathrm{U} / \mathrm{ml} \mathrm{IL-13} \mathrm{(50} \mathrm{ng/ml)} \mathrm{and} 500 \mathrm{U} / \mathrm{ml}$ IL-10 $(50 \mathrm{ng} / \mathrm{ml})$. Control RINm5F cells were grown in the absence of test compounds. The lower concentrations of proinflammatory cytokines are commonly used in $\beta$-cell research (Mandrup-Poulsen et al. 1987, 1990, Nerup et al. 1994, Lortz et al. 2000). The anti-inflammatory cytokine concentrations were chosen on the basis of preliminary concentration dependencies as the best suited for counteracting the effects of pro-inflammatory cytokines (data not shown).

\section{MTT cell viability assay}

In all sets of experiments, the viability of the cells was determined after a $24 \mathrm{~h}$ or $48 \mathrm{~h}$ incubation period using a 
microplate-based MTT assay (Mosmann 1983). The viability was expressed as \% of the MTT absorbance at 562/650 $\mathrm{nm}$ in the absence of test compounds.

\section{iNOS and MnSOD western blot analyses}

RINm5F cells were incubated for $24 \mathrm{~h}$ with cytokines, washed with ice-cold PBS and homogenised in ice-cold buffer $(50 \mathrm{mM}$ Tris-HCl, 1\% Triton T100, 5\% glycerol, pH 7.5) using short bursts (Braun-Sonic 125 Homogenisator, Quigley-Rochester, Inc., Rochester, NY, USA) and then heated up to $94^{\circ} \mathrm{C}$ for $3 \mathrm{~min}$. Cell homogenates were centrifuged at $9000 \mathrm{~g}$ and $4{ }^{\circ} \mathrm{C}$ for $10 \mathrm{~min}$ and the supernatants were used for western blot analyses. Protein content was determined by the BCA assay (Pierce, Rockford, IL, USA). For the assays, $20 \mu \mathrm{g}$ (for $\mathrm{MnSOD}$ ) or $40 \mu \mathrm{g}$ (for iNOS) total protein were resolved in SDS polyacrylamide gel electrophoresis and then electroblotted onto membranes. The Ponceau staining was used as a loading control. Immunodetection was performed by specific primary antibodies against MnSOD (rabbit polyclonal, a kind gift from Dr. K Dobashi, Japan) or iNOS (NOS2 rabbit polyclonal IgG, Santa Cruz Biotechnology, Heidelberg, Germany) followed by exposition to secondary peroxidase-conjugated AffiniPure donkey anti-rabbit IgG $(\mathrm{H}+\mathrm{L})$ (Dianova, Hamburg, Germany). The hybrids were visualised through chemiluminescence using the ECL detection system after short exposure (2-3 $\mathrm{min})$ to autoradiography films. The intensity of the bands was quantified through densitometry with the GelPro Analyzer 4.0 program (Media Cybernetics, Silver Spring, MD, USA).

\section{Reporter gene assay}

For the NFKB enhancer element activity studies, $2 \times 10^{4}$ cells/well were seeded in 96-well plates $24 \mathrm{~h}$ before transient transfection was performed (jetPEI transfection reagent) and $48 \mathrm{~h}$ before addition of tested compounds for $6 \mathrm{~h}$. The pSEAP-NF- $\kappa$ B construct was used as described in detail earlier (Azevedo-Martins et al. 2003). Secreted alkaline phosphatase expression was measured using the PhosphaLight System kit (Applera, Darmstadt, Germany).

\section{Caspase-3 activity assay}

The fluorimetric method of cleavage of the DEVD was employed. Caspase-3 cleaves the DEVD (a tetrapeptide composed of Asp-Glu-Val-Asp) in the C side of the aspartate residuum. In case of the cytokine incubations, control and treated incubated RINm5F cells were washed with ice-cold PBS and harvested using a cell scraper and incubated in hypotonic lysis buffer containing Chaps and TritonX for $10 \mathrm{~min}$ in microfuge tubes on ice. In contrast to proinflammatory cytokines, the chemical compounds used in this study caused significant cell death even after short-time exposures. Therefore, in order to measure caspase- 3 activity in all cells, also the dying cells, after indicated time period the cells were directly harvested using a cell scraper, centrifuged at $800 \mathrm{~g}$ at $4{ }^{\circ} \mathrm{C}$ for $5 \mathrm{~min}$ and then the cell pellet was washed with ice-cold PBS and lysed as written for cytokines. Thereafter, the tubes were centrifuged at $12500 \mathrm{~g}$ at $4{ }^{\circ} \mathrm{C}$ for $10 \mathrm{~min}$ and the supernatants were stored at $-80{ }^{\circ} \mathrm{C}$ for measurement. For the assay, $20 \mu \mathrm{l}$ lysate, $10 \mu \mathrm{l}$ substrate and $70 \mu \mathrm{l}$ assay buffer were placed in 96-well plates in duplicate, and the fluorescence at $360 / 460 \mathrm{~nm}$ excitation/emission was measured every $5 \mathrm{~min}$ for $2 \mathrm{~h}$ at $37^{\circ} \mathrm{C}$. Total protein content was determined by the Bradford assay. Calculation of the specific activity of caspase-3 was done adjusting the delta fluorescence value at $60 \mathrm{~min}-0 \mathrm{~min}(\Delta \mathrm{FU})$ to the protein content and dividing the obtained value by the slope of the standard curve. All caspase-3 activity curves were linear in the time window chosen. The amount of fluorescence produced was calculated against a standard curve of AMC over the time. The threshold for the enzyme activity was set at $1000 \Delta \mathrm{FU} / \mathrm{h}$. The results are presented as $\%$ of untreated cells.

\section{$R N A$ isolation and $c D N A$ preparation}

Total RNA was obtained using the guanidine thiocyanate method (Chomczynski \& Sacchi 1987). The quality of the total RNA was verified in agarose gel electrophoresis. RNA was quantified spectrophotometrically at 260/280 nm. Thereafter, $2 \mu \mathrm{g}$ RNA was reverse transcribed into complementary DNA using an oligo-dT18TNV primer and a reverse transcriptase.

\section{Real-time RT-PCR}

The QuantiTect SYBR Green technology (QIAGEN), which uses a fluorescent dye that binds only double-stranded DNA, was employed. The reactions were performed by the DNA Engine Opticon Sequence Detection System (Biozym Diagnostik, Hess. Oldendorf, Germany). A total volume of $25 \mu$ was used for the PCRs. Samples were first denatured at $94{ }^{\circ} \mathrm{C}$ for $2 \mathrm{~min}$ followed by up to 30 PCR cycles. Each PCR cycle comprised melting at $94^{\circ} \mathrm{C}$ for $30 \mathrm{~s}$, annealing at $61-$ $63{ }^{\circ} \mathrm{C}$ for $30 \mathrm{~s}$ and extension at $72{ }^{\circ} \mathrm{C}$ for $30 \mathrm{~s}$. Each PCR amplification was performed in triplicate. The optimal parameters for the PCRs were empirically defined. The purity of the amplified PCR products was verified by melting curves. The standard curves for each gene were generated using the specific amplified fragment cloned into a plasmid vector (pCR II-TOPO, Invitrogen), and the amounts determined using a fluorimetric assay (PicoGreen DNA Quantitation Kit, Invitrogen). The primers used in this study are shown in Table 1.

\section{Data analysis}

Analyses of the real-time RT-PCR data and of the standard curve for the genes were performed by the Opticon Monitor v. 1.07 (MJ Research Inc., Waltham, MA, USA). Densitometry for the immunoblottings was done using specific 
Table 1 Sequences of the primers used for the real-time RT-PCR gene expression quantification. All amplicons were in the size ranging from 95 to $170 \mathrm{bp}$. GAPDH was used as housekeeping gene

\section{GenBank access}

Gene

GAPDH

Caspase-3

NM_017008

iNOS

NM_012922

D44591

MnSOD
NM_017051
$5^{\prime}$-Primer sequence- $3^{\prime}$
Fw: TCACCACCATGGAGAAGGC
Rv: GCTAAGCAGTTGGTGGTGCA
Fw: TTGGAACGAACGGACCTGTGG
Rv: TGTCTCAATACCGCAGTCCAGCTC
Fw: TCGTACTTGGGATGCTCCATGG
Rv: TCCTGCAGGCTCACGGTCAA
Fw: CСТCССТGACCTGCCTTACGACTA
Rv: TTCAGATTGTTCACGTAGGTCGCG

Fw, forward (sense) primer; Rv, reverse (antisense) primer.

software (Gel-Pro Analyzer v. 4.0, Media Cybernetics, Silver Spring, MD, USA). All data are expressed as means \pm s.E.M. Statistical analyses for each group were performed by the Prism analysis program (Graphpad, San Diego, CA, USA).

\section{Results}

\section{Effects of cytokines on $N F \kappa B$ enhancer element activation}

To study the effects of cytokines on early events in the cytokine-induced cell death signalling cascade, the activation of the transcription factor $\mathrm{NF \kappa B}$ was analyzed. Incubation of insulin-producing RINm5F cells for $6 \mathrm{~h}$ with IL-1 $\beta$ resulted in a significant, concentration-dependent activation of the NFאB enhancer element (Table 2). TNF $\alpha$ and to a lesser extent IFN $\gamma$ enhanced IL-1 $\beta$-stimulated NFKB induction. A combination of all three pro-inflammatory cytokines (60 U/ml IL-1 $\beta, 185 \mathrm{U} / \mathrm{ml} \mathrm{TNF} \alpha, 14 \mathrm{U} / \mathrm{ml} \mathrm{IFN} \gamma)$ strongly stimulated NFKB activation. TNF $\alpha(185 \mathrm{U} / \mathrm{ml})$ alone increased NFKB activity slightly, while IFN $\gamma(140 \mathrm{U} / \mathrm{ml})$ alone did not significantly activate NFKB (Table 2). The antiinflammatory cytokines IL-4, IL-13 and IL-10 did not induce $\mathrm{NF} \kappa \mathrm{B}$ activation, but rather decreased IL-1 $\beta$-stimulated

Table 2 Effects of pro- or anti-inflammatory cytokines in insulin-producing RINm5F cells on NFkB activation and the inducible nitric oxide synthase (iNOS) and manganese superoxide dismutase (MnSOD) gene expression. Insulin-producing RINm5F cells were exposed for $6 \mathrm{~h}$ to the indicated compounds. Results are presented as fold increase comparing against control values obtained from cells incubated without the compounds. Normalisation of the real-time PCR curves was done against GAPDH. Data are mean values for the indicated number $(n)$ of independent experiments, in each measured in at least three repetitions

NFKB induction

RINm5F

Untreated

IL-1 (60)

IL-1 (600)

TNF (185)

TNF (1850)

IFN (14)

IFN (140)

IL-1 + TNF

IL-1 + IFN

TNF+IFN

Mix

IL-4 (500)

IL-1 + IL-4

IL-13 (500)

IL-1 + IL-13

IL-10 (500)

IL-1 + IL-10

Camptothecin (0.5)
iNOS expression

$1 \cdot 0 \pm 0 \cdot 1(20)$
$800 \pm 109(6)^{*}$
$1982 \pm 223(5)^{*, \dagger}$
$22 \pm 4(7)$
$37 \pm 15(7)$
$2 \cdot 2 \pm 0 \cdot 3(4)$
$3 \cdot 3 \pm 0 \cdot 8(5)$
$844 \pm 75(4)^{*, \neq}$
$833 \pm 209(4)^{*, \S}$
$5 \cdot 2 \pm 1 \cdot 1(4)$
$1024 \pm 122(6)^{*, \neq, \S}$
$0 \cdot 9 \pm 0 \cdot 2(4)$
$61 \pm 7(4)^{\dagger}$
$1 \cdot 4 \pm 0 \cdot 4(4)$
$65 \pm 20(4)^{\dagger}$
$1 \cdot 0 \pm 0 \cdot 3(3)$
$133 \pm 40(3)^{\dagger}$
$1 \cdot 0 \pm 0 \cdot 2(3)$

MnSOD expression

$1 \cdot 0 \pm 0 \cdot 1(20)$
$1 \cdot 8 \pm 0 \cdot 2(13)^{*}$
$2 \cdot 5 \pm 0 \cdot 2(12)^{*,+}$
$1 \cdot 4 \pm 0 \cdot 1(18)$
$1 \cdot 5 \pm 0 \cdot 0(18)$
$1 \cdot 2 \pm 0 \cdot 1(10)$
$1 \cdot 2 \pm 0 \cdot 1(20)$
$2 \cdot 5 \pm 0 \cdot 2(20)^{*,+, \neq}$
$2 \cdot 2 \pm 0 \cdot 2(20)^{*, \S}$
$1 \cdot 3 \pm 0 \cdot 1(20)$
$2 \cdot 4 \pm 0 \cdot 1(40)^{*,+, \neq, \S}$
$1 \cdot 3 \pm 0 \cdot 1(20)$
$1 \cdot 2 \pm 0 \cdot 1(20)^{\dagger}$
$1 \cdot 1 \pm 0 \cdot 1(20)$
$1 \cdot 4 \pm 0 \cdot 1(20)^{\dagger}$
$1 \cdot 3 \pm 0 \cdot 1(20)$
$1 \cdot 4 \pm 0 \cdot 1(20)^{\dagger}$
$0 \cdot 8 \pm 0 \cdot 1(4)$

$1 \cdot 0 \pm 0 \cdot 1(12)$

$6 \cdot 2 \pm 1 \cdot 2(4)^{*}$

$10 \pm 2(5)^{*}$

$2 \cdot 6 \pm 0 \cdot 2$ (4)

$3 \cdot 9 \pm 0 \cdot 8(4) *$

$0 \cdot 7 \pm 0 \cdot 1$ (7)

$1 \cdot 4 \pm 0 \cdot 2(4)$

$8 \cdot 3 \pm 1 \cdot 7(4)^{*, \neq}$

$6 \cdot 5 \pm 1 \cdot 8(4)^{*, \$}$

$2 \cdot 6 \pm 0 \cdot 2$ (5)

$9 \cdot 3 \pm 2 \cdot 0(5)^{*, \neq, \S}$

$1 \cdot 2 \pm 0 \cdot 2(4)$

$9 \cdot 9 \pm 2 \cdot 6(3)^{*, 11}$

$1 \cdot 7 \pm 0 \cdot 4$ (2)

$9 \cdot 2 \pm 2 \cdot 2(5)^{*, 9}$

$1 \cdot 0 \pm 0 \cdot 1$ (4)

$11 \pm 2(3)^{*, a}$

$0 \cdot 9 \pm 0 \cdot 2(3)$

Numbers in brackets represent the concentration of the compound in $\mathrm{U} / \mathrm{ml}$ or $\mu \mathrm{M}$ (for camptothecin). ${ }^{*} P<0 \cdot 05$ versus control; ${ }^{\dagger} P<0 \cdot 05$ versus IL-1 $\beta 60 \mathrm{U} / \mathrm{ml}$; ${ }^{\ddagger} P<0.05$ versus TNF $\alpha ;{ }^{\S} P<0.05$ versus IFN $\gamma ; "{ }^{\|} P<0.05$ versus IL-4; ${ }^{\circledR} P<0.05$ versus IL- $13,{ }^{a} P<0.05$ versus IL-10, ANOVA followed by Bonferroni test. The

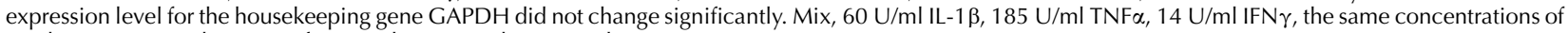
cytokines were used in case of co-incubations with two cytokines. 
NFкB activation (Table 2). The pro-apoptotic caspase-3 activator camptothecin failed to activate the $\mathrm{NF \kappa B}$ enhancer element (Table 2).

Effect of cytokines on expression of genes mediating cell death and survival

The induction of the iNOS gene in insulin-producing RINm5F cells was basically an IL- $1 \beta$-mediated event (Table 2). IL-1 $\beta$-stimulated iNOS gene expression achieved a maximum $5 \mathrm{~h}$ after addition of the cytokine (Fig. 2). The effect of IL-1 $\beta$ on iNOS gene expression was concentration dependent (Table 2). The pro-inflammatory cytokines TNF $\alpha$ and IFN $\gamma$ neither alone nor in combination significantly induced iNOS gene expression (Table 2). However, a combination of all three pro-inflammatory cytokines induced a more potent stimulatory effect on iNOS gene expression than $60 \mathrm{U} / \mathrm{ml} \mathrm{IL-1} \beta$ alone (Table 2). Interestingly, TNF $\alpha$ in combination with IL-1 $\beta$ also showed an additive effect (Table 2).

IL-4 (500 U/ml), IL-13 (500 U/ml) and IL-10 (500 U/ml) did not affect iNOS gene expression. However, all antiinflammatory cytokines significantly decreased iNOS gene expression induced by IL-1 $\beta$, an effect that was particularly evident with IL-4 and IL-13. The pro-apoptotic caspase-3 activator camptothecin did not affect iNOS expression.

MnSOD gene expression was also affected by cytokine treatment (Table 2). After exposure to IL-1 $\beta$ (60 U/ml) insulinproducing RINm5F cells exhibited a significant increase in MnSOD gene expression when compared with control cells (Table 2). Higher concentrations of IL-1 $\beta(600 \mathrm{U} / \mathrm{ml})$ further increased this effect. While a low concentration of TNF $\alpha$ (185 U/ml) did not significantly affect MnSOD gene expression, a higher concentration of this cytokine $(1850 \mathrm{U} / \mathrm{ml})$ caused a significant increase of MnSOD gene expression. IFN $\gamma$ (14 and $140 \mathrm{U} / \mathrm{ml}$ ) did not affect the expression of MnSOD and did not induce any synergistic effect in combination with IL-1 $\beta$ or TNF $\alpha$. The combination of three pro-inflammatory cytokines increased MnSOD expression to a level similar to that found after exposure to IL-1 $\beta$ plus TNF $\alpha$. IL-4 (500 U/ml), IL-13 $(500 \mathrm{U} / \mathrm{ml})$ and IL-10 $(500 \mathrm{U} / \mathrm{ml})$ did not affect MnSOD gene expression. Moreover, combinations of IL-4, IL-13 or IL-10 plus IL-1 $\beta$ did not show a significant additive effect. Again, camptothecin did not modulate MnSOD expression.

The caspase- 3 gene expression levels were not affected by any of the different cytokine treatments after a $6 \mathrm{~h}$ incubation time (data not shown). A time-dependent effect to the exposure to a high concentration of IL-1 $\beta$ (600 U/ml) revealed a small significant increase in caspase- 3 gene expression only after a $4 \mathrm{~h}$ incubation time (Fig. 1).

\section{Effects of cytokines on iNOS and MnSOD protein expression}

There was no iNOS protein detectable in untreated insulinproducing RINm5F cells (Table 3 and Fig. 3). Induction of iNOS protein was basically an IL- $1 \beta$-mediated effect, as shown in Table 3 and Fig. 3. A time course analysis of iNOS

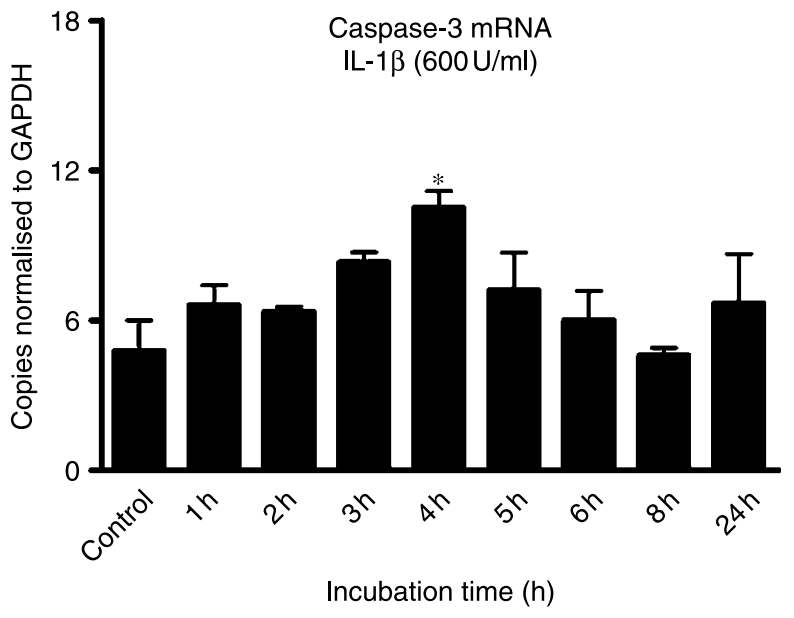

Figure 1 Time-dependent effect of IL-1 $\beta$ on the caspase- 3 gene expression in insulin-producing cells. RINm5F cells were incubated with $600 \mathrm{U} / \mathrm{ml} \mathrm{IL-1 \beta}$. The mRNA was obtained using the guanidinethiocyanate method. After reverse transcription, gene expression was measured by quantitative real-time PCR at 0 (no cytokines added, control), 1, 2, 3, 4, 5, 6, 8 and $24 \mathrm{~h}$ after incubation. $n=4$. ${ }^{*} P<0 \cdot 05$, ANOVA followed by Bonferroni.

Table 3 Effects of pro- or anti-inflammatory cytokines in insulinproducing RINm5F cells on the inducible nitric oxide synthase (iNOS) and manganese superoxide dismutase (MnSOD) protein expression, insulin-producing RINm5F cells were exposed for $24 \mathrm{~h}$ to the indicated compounds. Numbers in brackets represent the concentration of the compound in $\mathrm{U} / \mathrm{ml}$. Results are presented as \% or fold increase comparing against control values obtained from cells incubated without cytokines. Data are mean values for the indicated number $(n)$ of independent experiments

\begin{tabular}{|c|c|c|}
\hline & $\begin{array}{c}\text { iNOS expression } \\
(\% \text { of IL-1 60) }\end{array}$ & $\begin{array}{l}\text { MnSOD expression } \\
\text { (fold induction) }\end{array}$ \\
\hline \multicolumn{3}{|l|}{ RINm5F } \\
\hline Untreated & n.d $\pm 0(8)$ & $1 \cdot 0 \pm 0 \cdot 1(5)$ \\
\hline IL-1 (60) & $100 \pm 2(6)$ & $2 \cdot 4 \pm 0 \cdot 2(10)^{*}$ \\
\hline IL-1 (600) & $274 \pm 42(8)^{+}$ & $2 \cdot 7 \pm 0 \cdot 6(5)^{*}$ \\
\hline TNF (185) & $\mathrm{n} . \mathrm{d} \pm 0(7)$ & $1 \cdot 6 \pm 0 \cdot 2(6)^{*}$ \\
\hline TNF (1850) & n.d $\pm 0(7)$ & $1 \cdot 8 \pm 0 \cdot 2(4)^{*}$ \\
\hline IFN (14) & n.d $\pm 0(4)$ & $1 \cdot 2 \pm 0 \cdot 3(6)$ \\
\hline IFN (140) & $\mathrm{n} . \mathrm{d} \pm 0$ & $1 \cdot 5 \pm 0 \cdot 4(4)$ \\
\hline IL-1 + TNF & $145 \pm 14(3)^{\dagger}$ & $3 \cdot 0 \pm 0 \cdot 4(5)^{*}$ \\
\hline IL-1 + IFN & $97 \pm 18$ & $1 \cdot 7 \pm 0 \cdot 1(4)^{*}$ \\
\hline TNF+IFN & n.d $\pm 0(4)$ & $1 \cdot 7 \pm 0 \cdot 1(6)^{*}$ \\
\hline Mix & $254 \pm 75(6)^{\dagger}$ & $3 \cdot 0 \pm 0 \cdot 4(4)^{*}$ \\
\hline IL-4 (500) & n.d $\pm 0 \cdot 2(4)$ & $1 \cdot 1 \pm 0 \cdot 1$ \\
\hline IL-1 + IL-4 & $60 \pm 9(6)^{t}$ & $2 \cdot 2 \pm 0 \cdot 4(7)$ \\
\hline IL-13 (500) & n.d $\pm 0(4)$ & $0.9 \pm 0.2$ \\
\hline IL-1 + IL-13 & $67 \pm 18(4)^{\dagger}$ & $2 \cdot 1 \pm 0 \cdot 7(7)$ \\
\hline IL-10 (500) & n.d $\pm 0 \cdot 3(4)$ & $1 \cdot 1 \pm 0 \cdot 1$ \\
\hline IL-1 + IL-10 & $65 \pm 18(4)^{\dagger}$ & $2 \cdot 3 \pm 0 \cdot 6(7)$ \\
\hline
\end{tabular}

${ }^{*} P<0.05$ versus control, Dunnett's test; ${ }^{\dagger} P<0.05$ versus IL-1 $\beta 60$ t-test.

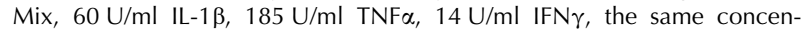
trations of cytokines were used in case of co-incubations with two cytokines. 
protein expression showed a delayed increase of protein expression in comparison with gene expression. The expression of iNOS protein became evident after a 3- to $4 \mathrm{~h}$ exposure and achieved a maximal expression level after an $8 \mathrm{~h}$ exposure to IL-1 $\beta(600 \mathrm{U} / \mathrm{ml})$, which remained stable up to $24 \mathrm{~h}$ (Fig. 3). Thus, maximal iNOS protein expression was delayed by around $3 \mathrm{~h}$ when compared with maximal iNOS gene expression (Figs 2 and 3). iNOS protein was not detected after $24 \mathrm{~h}$ incubation of the cells with TNF $\alpha$ at both low and high concentrations (185 and $1850 \mathrm{U} / \mathrm{ml})$ and also after exposure of the cells to both low and high concentrations of IFN $\gamma$ (14 and $140 \mathrm{U} / \mathrm{ml}$; Table 3$)$. TNF $\alpha$ showed a synergistic effect with IL-1 $\beta$ (Table 3 ). The combination of IL-1 $\beta$ with IFN $\gamma$ did not have an additive effect when compared with IL-1 $\beta$ alone (Table 3 ). The combination of $\mathrm{TNF} \alpha$ and IFN $\gamma$ did not induce iNOS protein expression (Table 3). A combination of all three pro-inflammatory cytokines $(60 \mathrm{U} / \mathrm{ml}$ IL-1 $\beta, 185 \mathrm{U} / \mathrm{ml} \mathrm{TNF} \alpha, 14 \mathrm{U} / \mathrm{ml}$ IFN $\gamma$ ) strongly induced iNOS protein expression. IL-4 $(500 \mathrm{U} / \mathrm{ml})$, IL-13 $(500 \mathrm{U} / \mathrm{ml})$ and IL-10 $(500 \mathrm{U} / \mathrm{ml}) \mathrm{did}$ not affect iNOS protein expression. However, all three antiinflammatory cytokines significantly decreased IL-1 $\beta$ induced iNOS protein expression, an effect that was particularly evident with IL-4 (Table 3).

MnSOD protein expression was affected by $24 \mathrm{~h}$ cytokine treatment (Table 3). After exposure to IL-1 $\beta$ (60 U/ml) insulinproducing RINm5F cells exhibited a significant increase of MnSOD protein expression when compared with control cells. Higher concentrations of IL-1 $\beta(600 \mathrm{U} / \mathrm{ml})$ further potentiated

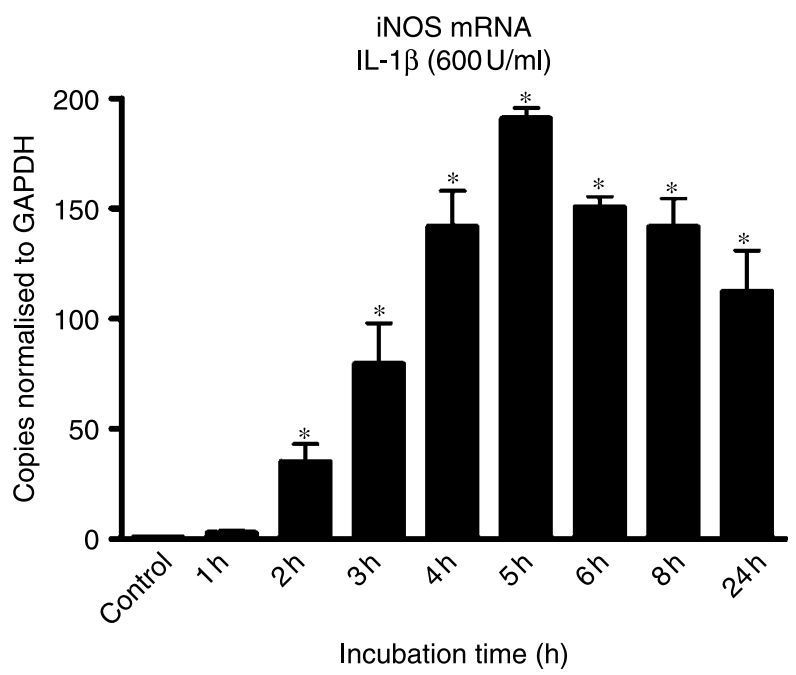

Figure 2 Time-dependent effect of IL-1 $\beta$ on the iNOS gene expression in insulin-producing cells. RINm5F cells were seeded $24 \mathrm{~h}$ before the incubation with $600 \mathrm{U} / \mathrm{ml} \mathrm{IL-1 \beta}$. The mRNA was obtained using the guanidine-thiocyanate method. After reverse transcription, gene expression was measured by quantitative realtime PCR at 0 (no cytokines added, control), 1, 2, 3, 4, 5, 6, 8 and $24 \mathrm{~h}$ after incubation. The means of absolute values from four to eight independent experiments are shown. ${ }^{*} P<0 \cdot 05$, ANOVA followed by Bonferroni.
iNOS protein expression

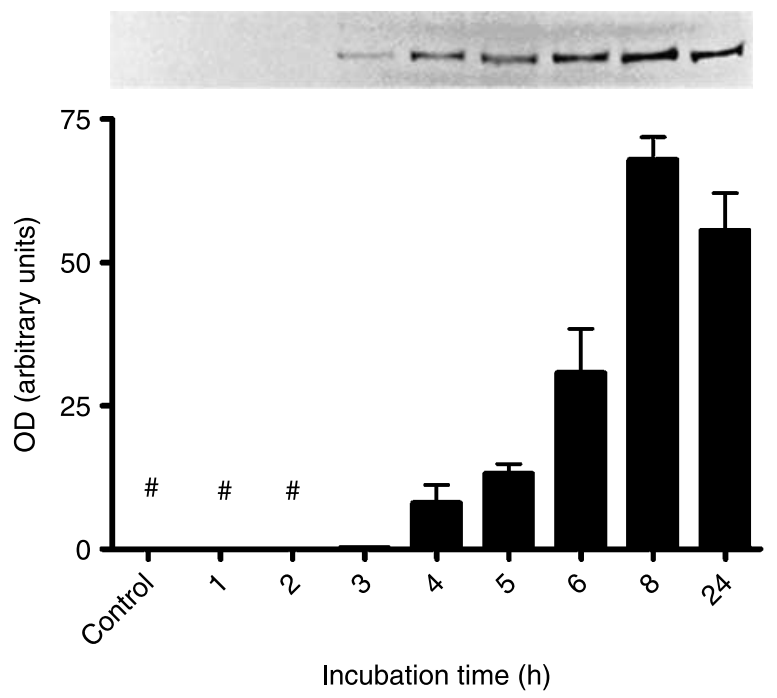

Figure 3 Time-dependent effect of IL-1 $\beta$ on the iNOS protein expression in insulin-producing cells. RINm5F cells were seeded $24 \mathrm{~h}$ before the incubation with $600 \mathrm{U} / \mathrm{ml} \mathrm{IL}-1 \beta$. The cells were lysed and used for western blot analyses at 0 (no cytokines added, lane $C$, control), 1, 2, 3, 4, 5, 6, 8 and $24 \mathrm{~h}$ after incubation. \#not detectable. A representative blot of four independent experiments is shown.

this effect. Both, low and high concentrations of TNF $\alpha$ significantly enhanced MnSOD protein expression (Table 3). IFN $\gamma(14$ and $140 \mathrm{U} / \mathrm{ml})$ did not affect MnSOD protein expression and did not induce any synergistic effect in combination with IL- $1 \beta$ or TNF $\alpha$ (Table 3 ). The combination of IL-1 $\beta 60 \mathrm{U} / \mathrm{ml}$ and TNF $\alpha 185 \mathrm{U} / \mathrm{ml}$ or of three pro-inflammatory cytokines increased MnSOD expression to a level similar to that found after exposure to $600 \mathrm{U} / \mathrm{ml} \mathrm{IL}-1 \beta$ (Table 3). IL-4 (500 U/ml), IL-13 (500 U/ml) and IL-10 $(500 \mathrm{U} / \mathrm{ml})$ did not affect MnSOD protein expression. A combination of IL-1 $\beta$ with anti-inflammatory cytokines did not significantly affect IL- $1 \beta$-stimulated MnSOD protein expression when compared with IL-1 $\beta$ alone. Camptothecin did not affect the protein expression of iNOS or MnSOD.

\section{Effect of cytokines on cell viability}

Incubation of control RINm5F cells with the pro-inflammatory cytokines IL-1 $\beta$, TNF $\alpha$ and IFN $\gamma$ for 24 and $48 \mathrm{~h}$ caused a loss of cell viability in the MTT assay, which was more pronounced in the case of the $48 \mathrm{~h}$ incubation (Table 4).

Only high concentrations of $600 \mathrm{U} / \mathrm{ml} \mathrm{IL-1 \beta}$ and the combination of TNF $\alpha$ and IFN $\gamma$ significantly induced cell death after $24 \mathrm{~h}$ (Table 4). The most toxic effects were observed in case of a mixture of all three pro-inflammatory cytokines IL-1 $\beta$, TNF $\alpha$ and IFN $\gamma(60,185$, and $14 \mathrm{U} / \mathrm{ml}$ respectively) as evident from a more than $30 \%$ decrease in cell viability (Table 4). Even high concentrations of TNF $\alpha$ or 
Table 4 Cell viability and caspase- 3 activity of RINm5F cells exposed to cytokines. For cell viability, insulin-producing RINm5F cells were exposed to cytokines for 24 and $48 \mathrm{~h}$ in the indicated concentration. The measurements were done using the MTT assay. For caspase-3 activity, the RINm5F cells were exposed to the compounds in the indicated concentration for $8 \mathrm{~h}$, washed with ice-cold PBS and lysed as described in the Methods. After lysis of the cells and extraction of the total intracellular protein, the activity of caspase-3 was measured using the DEVD cleavage method. Data are mean values for the indicated number $(n)$ of independent experiments, in each measured in at least three repetitions

Cell viability (24 h)

\section{RINm5F}

Untreated

IL-1 (60)

IL-1 (600)

TNF (185)

TNF (1850)

IFN (14)

IFN (140)

IL-1 + TNF

IL-1 + IFN

TNF+IFN

Mix

IL-4 (500)

IL-1 + IL-4

Mix + IL-4

IL-13 (500)

IL-1 + IL-13

Mix + IL-13

IL-10 (500)

IL-1 + IL-10

Mix + IL-10

ANTI mix

IL-1 60+ANTI mix

IL-1 $600+$ ANTI mix

Mix + ANTI mix

Control iNOS blocker

IL-1 (60) + iNOS blocker

IL (600) + iNOS blocker

Mix+iNOS blocker

$100 \pm 2(3)$
$91 \pm 2(3)$
$84 \pm 2(3)^{*}$
$92 \pm 2(3)$
$90 \pm 2(3)$
$95 \pm 2(3)$
$97 \pm 3(3)$
$93 \pm 5(4)^{\oplus}$
$93 \pm 3(4)^{\natural}$
$80 \pm 2(4)^{*}$
$68 \pm 2(3)^{*}$
$104 \pm 2(3)$
$102 \pm 3(3)$
$80 \pm 3(3)^{*}$
$104 \pm 2(3)$
$94 \pm 2(3)$
$85 \pm 3(4)^{*, 9}$
$112 \pm 3(3)$
$94 \pm 3(3)$
$84 \pm 3(4)^{*, 9}$
$101 \pm 1(4)$
$97 \pm 2(4)$
$86 \pm 2(4)$
$76 \pm 2(4)^{*, 9}$
$97 \pm 3(4)$
$95 \pm 2(4)$
$82 \pm 2(4)^{*}$
$86 \pm 2(4)^{*, 9}$

Cell viability (48 h)

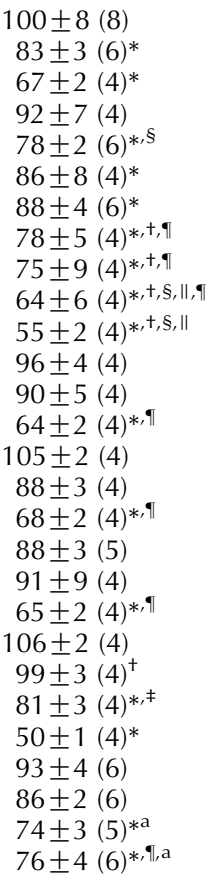

Caspase-3 activity (8 h)

$$
\begin{gathered}
100 \pm 5(8) \\
563 \pm 44(4)^{*} \\
1118 \pm 124(4)^{*} \\
111 \pm 7(4) \\
115 \pm 7(6) \\
105 \pm 12(3) \\
143 \pm 25(4) \\
495 \pm 88(4)^{*} \\
269 \pm 32(4)^{*} \\
295 \pm 27(4)^{*} \\
422 \pm 25(4)^{*} \\
110 \pm 7(4)^{\dagger} \\
146 \pm 3(4)^{\dagger} \\
121 \pm 12(5)^{\uparrow} \\
117 \pm 14(5) \\
239 \pm 51(4)^{*} \\
189 \pm 19(6)^{\oplus} \\
142 \pm 10(8) \\
155 \pm 14(6)^{\dagger} \\
165 \pm 17(5)^{\top} \\
83 \pm 17(3) \\
102 \pm 12(3)^{\dagger} \\
74 \pm 16(3)^{\ddagger} \\
90 \pm 11(7)^{\oplus} \\
105 \pm 11(4) \\
340 \pm 40(7)^{*,+, a} \\
404 \pm 43(4)^{*, \neq, a} \\
362 \pm 29(6)^{*, \uparrow, a}
\end{gathered}
$$

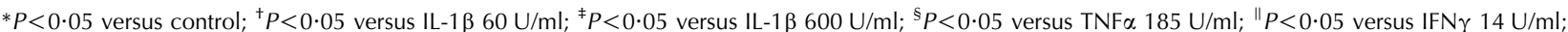
" $P<0.05$ versus Mix; ${ }^{\mathrm{a}} P<0.05$ versus control iNOS blocker. ANOVA followed by Bonferroni. Mix, $60 \mathrm{U} / \mathrm{ml}$ IL-1 $\beta, 185 \mathrm{U} / \mathrm{ml} \mathrm{TNF} \alpha, 14 \mathrm{U} / \mathrm{ml}$ IFN $\gamma$.

IFN $\gamma$ failed to decrease cell viability after $24 \mathrm{~h}$ (Table 4$)$. The anti-inflammatory cytokines IL-4 (500 U/ml), IL-13 $(500 \mathrm{U} / \mathrm{ml})$ and IL-10 $(500 \mathrm{U} / \mathrm{ml})$ did not affect $\beta$-cell viability after $24 \mathrm{~h}$ incubation either when was used each alone or in the combination (ANTI-mix; Table 4). A combination of anti-inflammatory cytokines with IL-1 $\beta(60 \mathrm{U} / \mathrm{ml})$ did not significantly affect cell viability when compared with IL-1 $\beta$ alone (Table 4). Interestingly, however, anti-inflammatory cytokines partially prevented the loss of cell viability in insulin-producing cells caused by a cytokine combination consisting of IL-1 $\beta$, TNF $\alpha$ and IFN $\gamma(60,185$ and $14 \mathrm{U} / \mathrm{ml}$ respectively; Table 4$)$.

After $48 \mathrm{~h}, \mathrm{IL}-1 \beta(600 \mathrm{U} / \mathrm{ml})$ reduced the cell viability by around $30 \%$ (Table 4). IL-1 $\beta$, TNF $\alpha$ and IFN $\gamma$ added in low concentrations $(60,185$ and $14 \mathrm{U} / \mathrm{ml}$ respectively) to the incubation medium each decreased the viability by around 5-15\% (Table 4). TNF $\alpha$ and IFN $\gamma$ each slightly potentiated IL-1 $\beta$-induced $\beta$-cell loss leading to a loss of $20-25 \%$ (Table 4). Treatment of insulin-producing cells with a combination of TNF $\alpha$ and IFN $\gamma$ reduced the cell viability by around 35\% (Table 4). As expected the most toxic combination of cytokines was the mixture of IL-1 $\beta$, TNF $\alpha$ and IFN $\gamma$ (60, 185 and $14 \mathrm{U} / \mathrm{ml}$, respectively) as evident from a roughly $50 \%$ reduction of the cell viability when compared with untreated cells (Table 4).

The anti-inflammatory cytokines IL-4, IL-13 and IL-10 did not affect $\beta$-cell viability either after $48 \mathrm{~h}$ (Table 4). A combination of anti-inflammatory cytokines with IL-1 $\beta$ $(60 \mathrm{U} / \mathrm{ml})$ again, like in case of a $24 \mathrm{~h}$ incubation, did not significantly affect cell viability when compared with IL-1 $\beta$ alone (Table 4). Each of the anti-inflammatory cytokines alone was able to partially prevent the loss of cell viability in insulin-producing cells caused by a cytokine combination consisting of IL-1 $\beta$, TNF $\alpha$ and IFN $\gamma(60,185$ and $14 \mathrm{U} / \mathrm{ml}$ respectively; Table 4). The mixture of all three antiinflammatory cytokines did not affect cell viability after $48 \mathrm{~h}$ incubation (Table 4). ANTI-mix significantly protected against IL- $1 \beta$-induced $\beta$-cell loss, failed, however, to counteract the toxicity of the pro-inflammatory cytokine mixture (Table 4). 
Table 5 Cell viability and caspase- 3 activity of RINm5F cells exposed to cytotoxic chemical compounds. For cell viability, insulin-producing RINm5F cells were exposed for 24 and $48 \mathrm{~h}$ to chemical compounds in the indicated concentration. The measurements were done using the MTT assay. For caspase- 3 activity, the RINm5F cells were exposed to the compounds in the indicated concentration for $8 \mathrm{~h}$ and lysed as described in the Methods. After lysis of the cells and extraction of the total intracellular protein, the activity of caspase- 3 was measured using the DEVD cleavage method. Data are mean values for the indicated number $(n)$ of independent experiments, in each measured in at least 3 repetitions

Cell viability (24 h)

RINm5F

Untreated

Camptothecin $(0.5 \mu \mathrm{M})$

SNAP $(0 \cdot 1 \mathrm{mM})$

$\operatorname{SNAP}(1 \mathrm{mM})$

$$
\begin{gathered}
100 \pm 2(4) \\
54 \pm 7(4)^{*} \\
79 \pm 4(4)^{*} \\
50 \pm 4(4)^{*}
\end{gathered}
$$

Cell viability (48 h)

$$
\begin{array}{r}
100 \pm 8(4) \\
12 \pm 1(4)^{*} \\
79 \pm 3(3)^{*} \\
3 \pm 0(3)^{*}
\end{array}
$$

Caspase-3 activity (8 h)

$100 \pm 5(8)$

$1150+487(4)^{*}$

$443 \pm 75(6)^{*}$

$844 \pm 115(5)^{*}$

${ }^{*} P<0 \cdot 05$ versus control. ANOVA followed by Bonferroni. SNAP, S-nitroso-n-acetylpenicillamine.

Exposure of insulin-producing RINm5F cells to cytotoxic chemical compounds resulted in impaired cell viability as shown in Table 5 . This was especially evident after treatment with a high concentration of the nitric oxide-donor SNAP $(1 \mathrm{mM})$ and with the pro-apoptotic caspase-3 activator camptothecin $(0 \cdot 5 \mu \mathrm{M})$. Incubation of insulin-producing cells with the iNOS blocker L-NOARG $(5 \mathrm{mmol} / \mathrm{l})$ significantly decreased toxicity induced by the combination of all three pro-inflammatory cytokines (Table 4).

\section{Effect of cytokines on caspase-3 enzyme activity}

The time dependent effect on caspase-3 enzyme activity in response to pro-inflammatory cytokines and camptothecin is shown in Fig. 4. High concentrations of IL- $1 \beta$ strongly increased caspase- 3 activity starting at $8 \mathrm{~h}$ incubation (Fig. 4).

Caspase- 3 activity in response to high concentrations of TNF $\alpha(1850 \mathrm{U} / \mathrm{ml})$ showed after a transient decrease in activity at 2 and $4 \mathrm{~h}$, a significant increase of activity at $24 \mathrm{~h}$ (Fig. 4). However, the effect was weaker than that of IL-1 $\beta$ $600 \mathrm{U} / \mathrm{ml}$. IFN $\gamma(14$ and $140 \mathrm{U} / \mathrm{ml})$ did not affect caspase-3 activity (Fig. 4 and Table 4 ). A combination of the three proinflammatory cytokines $(60 \mathrm{U} / \mathrm{ml} \mathrm{IL}-1 \beta, 185 \mathrm{U} / \mathrm{ml} \mathrm{TNF} \alpha$, $14 \mathrm{U} / \mathrm{ml}$ IFN $\gamma$ ) increased caspase-3 activity already at $4 \mathrm{~h}$ and reached a maximum at $8 \mathrm{~h}$ (Fig. 4). However, the increase was less than that of a high concentration of IL-1 $\beta(600 \mathrm{U} / \mathrm{ml})$. Camptothecin, used as a positive control, increased caspase-3 activity at $8 \mathrm{~h}$ with a further increase at $24 \mathrm{~h}$ (data not shown). Prior incubation for $10 \mathrm{~min}$ with the caspase-3 inhibitor Ac-DEVD-CHO ${ }_{2}$ kept the activity at levels near or below the control values, confirming the specificity of the measurement (data not shown).

Additionally, a comprehensive panel of incubations for $8 \mathrm{~h}$ with different combinations of cytokines is shown in Table 4 . Incubation of insulin-producing RINm5F cells with a low concentration of IL-1 $\beta(60 \mathrm{U} / \mathrm{ml})$ also resulted in increased caspase-3 activity (Table 4). Co-incubation of cells with IL-1 $\beta(60 \mathrm{U} / \mathrm{ml})$ and either IL-4 $(500 \mathrm{U} / \mathrm{ml})$, IL-13 $(500 \mathrm{U} / \mathrm{ml})$ or IL-10 $(500 \mathrm{U} / \mathrm{ml})$ decreased the activation of caspase-3 (Table 4). This antagonistic effect of the anti-inflammatory cytokines IL-4, IL-13 and IL-10 was more evident when the cells were co-incubated with the pro-inflammatory cytokine mixture (Table 4). While the treatment with the three pro-inflammatory cytokines resulted in a more than $400 \%$ increase in caspase-3 activity, co-incubation with IL-13 or IL-10 decreased the activity to half this level and co-incubation with IL-4 reduced the activity to levels near the control group (Table 4). Co-incubations of IL-1 $\beta$ alone or of pro-inflammatory cytokine mixture with the ANTI-mix completely prevented caspase-3 activation after $8 \mathrm{~h}$ (Table 4).

Use of the iNOS blocker L-NOARG $(5 \mathrm{mmol} / \mathrm{l})$ in the absence of pro-inflammatory cytokines did not affect caspase3 activity. Co-incubation of the cells with IL-1 $\beta(60 \mathrm{U} / \mathrm{ml}$ or

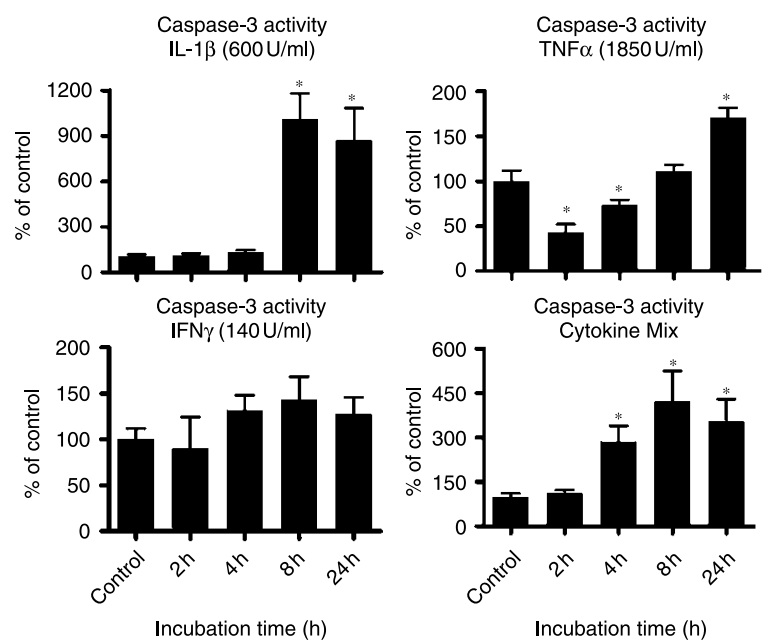

Figure 4 Time-response curve for caspase-3 activity after exposure of insulin-producing cells to cytokines. Insulin-producing RINm5F cells were exposed to cytokines in the indicated concentration for different periods of incubation. After lysis of the cells and extraction of the total intracellular protein, the activity of caspase- 3 was measured using the DEVD cleavage method. $n=4-8 .{ }^{*} P<0 \cdot 05$, ANOVA followed by Bonferroni. Mix, $60 \mathrm{U} / \mathrm{ml} \mathrm{IL-1 \beta ,} 185 \mathrm{U} / \mathrm{ml}$ $\mathrm{TNF} \alpha, 14 \mathrm{U} / \mathrm{ml}$ IFN $\gamma$. 
$600 \mathrm{U} / \mathrm{ml}$ ) plus the iNOS blocker L-NOARG significantly decreased caspase-3 activity when compared with IL-1 $\beta$ alone. Co-incubation with iNOS blocker failed, however, to prevent caspase- 3 activation caused by the mixture of the three pro-inflammatory cytokines (Table 5). Camptothecin and a NO-donor SNAP significantly and very pronouncedly induced caspase-3 activity in the present study (Table 5). It is important to mention that the high cell death rate caused by these very toxic chemical compounds even after $8 \mathrm{~h}$ incubation forced us to change the cell sample preparation procedure for caspase-3 in order to avoid washing away of dying and dead cells, which decrease the values for caspase-3 significantly.

\section{Discussion}

The pro-inflammatory cytokines induce cell death through complex signalling pathways (Eizirik et al. 1996b, MandrupPoulsen 1996, 2003a,b. Eizirik \& Mandrup-Poulsen 2001, Cnop et al. 2005). Specific cell death pathways are activated depending on the individual pro-inflammatory cytokine as well as the composition of the cytokine combinations to which the cells are exposed. It is generally accepted that proinflammatory cytokines are major effectors of programmed cell death during the onset of type 1 diabetes mellitus (Eizirik 1988, 1991, Eizirik et al. 1991, 1994, Sandler et al. 1992, Mandrup-Poulsen 1996, Eizirik \& Mandrup-Poulsen 2001, Cnop et al. 2005, Ronn et al. 2007). The mechanisms of action are only partially understood, but it is assumed that increased nitrosative and oxidative stresses (Lortz et al. 2000, Suarez-Pinzon et al. 2001, Bast et al. 2002, Lortz \& Tiedge 2003, Gurgul et al. 2004, Storling et al. 2005) play a crucial role. Therefore, induction of nitrosative pathways, such as generation of NO by iNOS (Eizirik et al. 1992, 1996b, Eizirik \& Leijerstam 1994, Eizirik \& Pavlovic 1997, Tiedge et al. 1999), and oxidative stress by upregulation of MnSOD (Azevedo-Martins et al. 2003, Qadri et al. 2004, Lortz et al. 2005) might play a key role in the mechanisms of cytokinemediated $\beta$-cell death. Upregulation of expression of these two genes leads always to increased protein expression and enzyme activity in insulin-producing cells (Tiedge et al. 1997). On the other hand, the anti-inflammatory cytokines IL-4, IL-13 and IL-10 may be involved in the protection of $\beta$-cells (Rapoport et al. 1993, Pennline et al. 1994, Racke et al. 1994, Kaminski et al. 2007) and other cell types (Paintlia et al. 2006).

IL-1 $\beta$ was the most potent inducer of NFKB and iNOS and MnSOD gene expression, effects that could be potentiated by other pro-inflammatory cytokines. Our results showed that $\mathrm{TNF} \alpha$ also activated these genes, although to a much lesser extent, and therefore a significant effect was visible on the protein level only for MnSOD but not for iNOS. IFN $\gamma$ $(14 \mathrm{U} / \mathrm{ml})$ by itself did not affect IL-1 $\beta$ - or TNF $\alpha$-induced iNOS or MnSOD gene and protein expression. However, a potentiation of the effects of IL- $1 \beta$ was observed in the presence of TNF $\alpha$. A potentiation by IFN $\gamma$ was observed only in the combination with IL-1 $\beta$ or TNF $\alpha$. An induction of gene and protein expression by these pro-inflammatory cytokines correlated always with a loss of cell viability and an activation of caspase-3 as a sign of apoptotic cell death.

All anti-inflammatory cytokines tested in the present study (IL-4, IL-13 and IL-10) antagonised the effects of proinflammatory cytokines on the activation of NFKB and the gene and protein expression of iNOS but not of MnSOD. In the same way, the effects of IL- $1 \beta$ and in particular of the proinflammatory cytokine mixture on caspase-3 activity and cytotoxicity were reduced. This supports the contention that the anti-inflammatory cytokines act in a protective way through antagonising the activation of the NFKB-mediated pathway of cell death, thereby suppressing nitrosative stress. Moreover, our results confirm earlier observations in different cell types which have shown that anti-inflammatory cytokines decrease the pro-inflammatory cytokine stimulated iNOS gene and protein expression and reduce NO release (Sandler \& Sternesjo 1995, Berkman et al. 1996, Plunkett et al. 2001, Paintlia et al. 2006). In case of a shorter $24 \mathrm{~h}$ incubation, the combination of three anti-inflammatory cytokines were also able to reduce pro-inflammatory cytokine toxicity. However, after $48 \mathrm{~h}$, this reduction of cytotoxic effects was seen only in the case of IL- $1 \beta$ but not in the case of the pro-inflammatory cytokine mixture. This can be due to a very intense attack of pro-inflammatory cytokines which is hard to counteract especially in the face of a very low level of anti-inflammatory cytokine receptor expression in insulin-producing RINm5F cells (E Gurgul-Convey, unpublished observation).

The mechanisms underlying the reduction of NFKB activation by anti-inflammatory cytokines, which may account for the decreased iNOS expression, range from de novo synthesis of I $\kappa \mathrm{B} \alpha$ (Molina-Holgado et al. 2002), interactions between STAT6 and upstream factors in signalling cascades activated by pro-inflammatory cytokines (Nelson et al. 2003) and transcription blockade by STAT6-mediated inhibition of NFKB binding to the promoter regions of the genes coding NFאB subunits (Bennett et al. 1997, Abu-Amer 2001) or prevention of NFKB translocation to the nuclear compartment (Ohmori \& Hamilton 2000, Molina-Holgado et al. 2002, Al-Ashy et al. 2006).

Previous studies have shown that TNF $\alpha$ activates caspases 3, 8 and 9 in different cell types (Alikhani et al. 2004) and that exposure of insulin-producing cells to IFN $\gamma$ causes activation of caspase-1 (Karlsen et al. 2000). IL-1 $\beta$ is able to activate caspase- 3 in $\beta$-cells and this effect is possibly linked to NO production (Chen et al. 2003, Veluthakal et al. 2004).

Studies with NO donors have previously shown that NO is toxic to insulin-producing cells (Tiedge et al. 1999, Storling et al. 2005), an observation that was corroborated through the present study. However, the relevance of $\mathrm{NO}$ in triggering cytokine-induced apoptotic cell death in insulin-producing cells is still not entirely clear. While some studies have shown an absolute importance of the NO pathway in cytokine-mediated $\beta$-cell apoptosis (Delaney et al. 1996, Eizirik \& Darville 2001, Storling et al. 2005), 
other experiments provided opposite results (Liu et al. 2000, Todaro et al. 2003, Zaitseva et al. 2006). From an in vitro point of view, our results indicate that the incubation of insulin-producing cells with pro-inflammatory cytokines and the NO-donor SNAP increased caspase-3 activity while the iNOS blocker L-NOARG reduced pro-inflammatory cytokine-induced caspase-3 activity. The pro-inflammatory cytokine-stimulated increase in caspase- 3 activity was also substantially blocked by co-incubation with IL-4, IL-13 or IL-10, which reduced iNOS expression. Early activation of apoptotic pathways by pro-inflammatory cytokines seems thus to be NO dependent. Our results also indicate a clear time-dependent induction of caspase- 3 by IL- $1 \beta$ or the proinflammatory cytokine combination at a very early stage. Notably, de novo synthesis of caspase- 3 does not seem to be essential or required for its activity. Interestingly, maximal IL-1 $\beta$-induced iNOS protein expression is reached at the same time point $(8 \mathrm{~h})$ as maximal IL- $1 \beta$-induced caspase-3 activity, which is an additional indication for a link between $\mathrm{NO}$ and apoptotic pathways.

Insulin-producing cells are not well equipped with hydrogen peroxide detoxifying enzymes, especially in the mitochondrial compartment (Gurgul et al. 2004), but express significant levels of the superoxide dismutating enzymes CuZnSOD and MnSOD (Lenzen et al. 1996, Tiedge et al. 1997). MnSOD resides in the mitochondrial compartment and is responsible for dismutation of superoxide radicals into hydrogen peroxide. As shown in earlier studies, proinflammatory cytokines significantly stimulate the expression of MnSOD and this event appears to play a crucial role in triggering cytokine toxicity in insulin-producing cells (Lortz et al. 2005). Nonetheless, it appears from our present studies that induction of MnSOD in the early phase of cytokine toxicity does not account for cytokine-mediated cell damage. Oxidative stress caused by induction of $\mathrm{MnSOD}$ requires a prolonged time to cause damage to cellular components and to cause cytotoxic effects mediated by pro-inflammatory cytokines in insulin-producing cells (Lortz et al. 2005).

Interestingly, co-incubations with anti-inflammatory cytokines, although beneficial for $\beta$-cell survival, did not prevent MnSOD induction stimulated by the pro-inflammatory cytokine IL-1 $\beta$. This is an additional indication that oxidative stress does not play a major role in the early phase of cytokinemediated toxicity. Of importance, the effects of the combined action of pro- and anti-inflammatory cytokines upon MnSOD expression could not be explained by NFKB activation. Our studies indicate that $\mathrm{NF} \kappa \mathrm{B}$ although important for induction of the MnSOD expression in insulin-producing cells is not the only relevant transcription factor involved in the transcription of this gene. It is possible therefore that other transcription factors, such as AP1 or Sp1, are involved in the modulation of MnSOD expression in insulin-producing cells, as has been shown in other cell types (Kaneko et al. 2004, Qadri et al. 2004).

In conclusion, our results indicate that in insulinproducing cells exposed to cytokines, nitrosative stress plays an important role in activating apoptotic pathways in the early phase of cytokine toxicity. This might be true especially when the pro-inflammatory cytokine concentration is high. The use of IL-4, IL-13 and IL-10 to block pro-inflammatory cytokine-induced activation of caspase- 3 may have important consequences for pancreatic $\beta$-cell protection and survival, in particular when the pro-inflammatory cytokine concentration is low or when only IL-1 $\beta$ is present. Thus, protection might be especially effective, when low concentrations of proinflammatory cytokines are released in the vicinity of the $\beta$-cells such as in the early phase of type 1 diabetes development or reach the $\beta$-cells via the circulation from distant sites of inflammation.

\section{Acknowledgements}

This work was supported by a grant from the Ministry of Science and Culture of Lower Saxony (K S) and by the European Union (STREP SAVEBETA in the Framework programme 6 of the European Community). The skilful technical assistance of B Lueken and S Lippold is gratefully acknowledged. The authors are grateful to Dr K Dobashi (Kitakyushu, Japan) for the antibodies against rat MnSOD. The authors declare that there is no conflict of interest that would prejudice the impartiality of this scientific work.

\section{References}

Abu-Amer Y 2001 IL-4 abrogates osteoclastogenesis through STAT6-dependent inhibition of NF-KB. Journal of Clinical Investigation 107 1375-1385.

Al-Ashy R, Chakroun I, El-Sabban ME \& Homaidan FR 2006 The role of $\mathrm{NF}-\mathrm{KB}$ in mediating the anti-inflammatory effects of IL-10 in intestinal epithelial cells. Cytokine $361-8$.

Alikhani M, Alikhani Z, Raptis M \& Graves DT 2004 TNF- $\alpha$ in vivo stimulates apoptosis in fibroblasts through caspase- 8 activation and modulates the expression of pro-apoptotic genes. Journal of Cellular Physiology 201 341-348.

Azevedo-Martins AK, Lortz S, Lenzen S, Curi R, Eizirik DL \& Tiedge M 2003 Improvement of the mitochondrial antioxidant defense status prevents cytokine-induced nuclear factor- $\mathrm{\kappa B}$ activation in insulin-producing cells. Diabetes 52 93-101.

Bast A, Wolf G, Oberbaumer I \& Walther R 2002 Oxidative and nitrosative stress induces peroxiredoxins in pancreatic beta cells. Diabetologia 45 867-876.

Bennett BL, Cruz R, Lacson RG \& Manning AM 1997 Interleukin-4 suppression of tumor necrosis factor $\boldsymbol{\alpha}$-stimulated E-selectin gene transcription is mediated by STAT6 antagonism of NF- $\mathrm{KB}$. Journal of Biological Chemistry 272 10212-10219.

Berkman N, Robichaud A, Robbins RA, Roesems G, Haddad EB, Barnes PJ \& Chung KF 1996 Inhibition of inducible nitric oxide synthase expression by interleukin- 4 and interleukin-13 in human lung epithelial cells. Immunology 89 363-367.

Callard RE, Matthews DJ \& Hibbert L 1996 IL-4 and IL-13 receptors: are they one and the same? Immunology Today 17 108-110.

Cetkovic-Cvrlje M \& Eizirik DL 1994 TNF-alpha and IFN-gamma potentiate the deleterious effects of IL- 1 beta on mouse pancreatic islets mainly via generation of nitric oxide. Cytokine 6 399-406. 
Chen HQ, Tannous M, Veluthakal R, Amin R \& Kowluru A 2003 Novel roles for palmitoylation of Ras in IL-1 beta-induced nitric oxide release and caspase 3 activation in insulin-secreting beta cells. Biochemical Pharmacology 66 1681-1694.

Chomczynski P \& Sacchi N 1987 Single-step method of RNA isolation by acid guanidinium thiocyanate-phenol-chloroform extraction. Analytical Biochemistry 162 156-159.

Cnop M, Welsh N, Jonas JC, Jorns A, Lenzen S \& Eizirik DL 2005 Mechanisms of pancreatic beta-cell death in type 1 and type 2 diabetes: many differences, few similarities. Diabetes 54 S97-S107.

Darville MI \& Eizirik DL 1998 Regulation by cytokines of the inducible nitric oxide synthase promoter in insulin-producing cells. Diabetologia 41 1101-1108.

Delaney CA, Tyrberg B, Bouwens L, Vaghef H, Hellman B \& Eizirik DL 1996 Sensitivity of human pancreatic islets to peroxynitrite-induced cell dysfunction and death. FEBS Letters 394 300-306.

Delaney CA, Pavlovic D, Hoorens A, Pipeleers DG \& Eizirik DL 1997 Cytokines induce deoxyribonucleic acid strand breaks and apoptosis in human pancreatic islet cells. Endocrinology 138 2610-2614.

Eizirik DL 1988 Interleukin-1 induced impairment in pancreatic islet oxidative metabolism of glucose is potentiated by tumor necrosis factor. Acta Endocrinologica 119 321-325.

Eizirik DL 1991 Interleukin-1 beta induces an early decrease in insulin release, (pro)insulin biosynthesis and insulin mRNA in mouse pancreatic islets by a mechanism dependent on gene transcription and protein synthesis. Autoimmunity 10 107-113.

Eizirik DL \& Leijerstam F 1994 The inducible form of nitric oxide synthase (iNOS) in insulin-producing cells. Diabetes and Metabolism 20 116-122.

Eizirik DL \& Pavlovic D 1997 Is there a role for nitric oxide in beta-cell dysfunction and damage in IDDM? Diabetes/Metabolism Reviews $\mathbf{1 3}$ 293-307.

Eizirik DL \& Darville MI 2001 Beta-cell apoptosis and defense mechanisms: lessons from type 1 diabetes. Diabetes 50 S64-S69.

Eizirik DL \& Mandrup-Poulsen T 2001 A choice of death - the signaltransduction of immune-mediated beta-cell apoptosis. Diabetologia 44 2115-2133.

Eizirik DL, Bendtzen K \& Sandler S 1991 Short exposure of rat pancreatic islets to interleukin-1 beta induces a sustained but reversible impairment in beta-cell function: influence of protease activation, gene transcription, and protein synthesis. Endocrinology 128 1611-1616.

Eizirik DL, Cagliero E, Bjorklund A \& Welsh N 1992 Interleukin-1 beta induces the expression of an isoform of nitric oxide synthase in insulinproducing cells, which is similar to that observed in activated macrophages. FEBS Letters 308 249-252.

Eizirik DL, Sandler S, Welsh N, Cetkovic-Cvrlje M, Nieman A, Geller DA, Pipeleers DG, Bendtzen K \& Hellerstrom C 1994 Cytokines suppress human islet function irrespective of their effects on nitric oxide generation. Journal of Clinical Investigation 93 1968-1974.

Eizirik DL, Delaney CA, Green MH, Cunningham JM, Thorpe JR, Pipeleers DG, Hellerstrom C \& Green IC 1996a Nitric oxide donors decrease the function and survival of human pancreatic islets. Molecular and Cellular Endocrinology 118 71-83.

Eizirik DL, Flodstrom M, Karlsen AE \& Welsh N $1996 b$ The harmony of the spheres: inducible nitric oxide synthase and related genes in pancreatic beta cells. Diabetologia 39 875-890.

Flodstrom M, Welsh N \& Eizirik DL 1996 Cytokines activate the nuclear factor kappa B (NF- $\kappa \mathrm{B})$ and induce nitric oxide production in human pancreatic islets. FEBS Letters 385 4-6.

Gurgul E, Lortz S, Tiedge M, Jorns A \& Lenzen S 2004 Mitochondrial catalase overexpression protects insulin-producing cells against toxicity of reactive oxygen species and proinflammatory cytokines. Diabetes $\mathbf{5 3}$ 2271-2280.

Joshi SG \& Sahni SK 2003 Immunofluorescent detection of activation of initiator caspases- 8 and -9 during pharmacologically induced apoptosis of cultured HeLa and endothelial cells. Histochemistry and Cell Biology 119 463-468.
Joshi SG, Francis CW, Silverman DJ \& Sahni SK 2003 Nuclear factor kappa B protects against host cell apoptosis during Rickettsia rickettsii infection by inhibiting activation of apical and effector caspases and maintaining mitochondrial integrity. Infection and Immunity 71 4127-4136.

Kaminski A, Kaminski ER \& Morgan NG 2007 Pre-incubation with interleukin-4 mediates a direct protective effect against the loss of pancreatic beta-cell viability induced by proinflammatory cytokines. Clinical Experimental Immunology 148 583-588.

Kaneko M, Takahashi T, Niinuma Y \& Nomura Y 2004 Manganese superoxide dismutase is induced by endoplasmic reticulum stress through IRE1-mediated nuclear factor (NF)-kappaB and AP-1 activation. Biological and Pharmaceutical Bulletin 27 1202-1206.

Karlsen AE, Pavlovic D, Nielsen K, Jensen J, Andersen HU, Pociot F, Mandrup-Poulsen T, Eizirik DL \& Nerup J 2000 Interferon-gamma induces interleukin- 1 converting enzyme expression in pancreatic islets by an interferon regulatory factor-1-dependent mechanism. Journal of Clinical Endocrinology and Metabolism 85 830-836.

Kotowicz K, Callard RE, Friedrich K, Matthews DJ \& Klein N 1996 Biological activity of IL-4 and IL-13 on human endothelial cells: functional evidence that both cytokines act through the same receptor. International Immunology 8 1915-1925.

Kraich M, Klein M, Patino E, Harrer H, Nickel J, Sebald W \& Mueller TD 2006 A modular interface of IL-4 allows for scalable affinity without affecting specificity for the IL-4 receptor. BMC Biology 413 .

Kuhn K, Shikhman AR \& Lotz M 2003 Role of nitric oxide, reactive oxygen species, and p38 MAP kinase in the regulation of human chondrocyte apoptosis. Journal of Cellular Physiology 197 379-387.

Kurrer MO, Pakala SV, Hanson HL \& Katz JD 1997 Beta cell apoptosis in T cell-mediated autoimmune diabetes. PNAS 94 213-218.

Laffranchi R \& Spinas GA 1996 Interleukin 10 inhibits insulin release from and nitric oxide production in rat pancreatic islets. European Journal of Endocrinology 135 374-378.

Ledeboer A, Breve JJ, Poole S, Tilders FJ \& Van Dam AM 2000 Interleukin10 , interleukin- 4 , and transforming growth factor-beta differentially regulate lipopolysaccharide-induced production of pro-inflammatory cytokines and nitric oxide in co-cultures of rat astroglial and microglial cells. Glia 30 134-142.

Lenzen S, Drinkgern J \& Tiedge M 1996 Low antioxidant enzyme gene expression in pancreatic islets compared with various other mouse tissues. Free Radical Biology and Medicine 20 463-466.

Lieb K, Engels S \& Fiebich BL 2003 Inhibition of LPS-induced iNOS and NO synthesis in primary rat microglial cells. Neurochemistry International 42 131-137.

Liu D, Pavlovic D, Chen MC, Flodstrom M, Sandler S \& Eizirik DL 2000 Cytokines induce apoptosis in beta-cells isolated from mice lacking the inducible isoform of nitric oxide synthase (iNOS $-/-$ ). Diabetes 49 1116-1122.

Lortz S \& Tiedge M 2003 Sequential inactivation of reactive oxygen species by combined overexpression of SOD isoforms and catalase in insulinproducing cells. Free Radical Biology and Medicine 34 683-688.

Lortz S, Tiedge M, Nachtwey T, Karlsen AE, Nerup J \& Lenzen S 2000 Protection of insulin-producing RINm5F cells against cytokine-mediated toxicity through overexpression of antioxidant enzymes. Diabetes $\mathbf{4 9}$ 1123-1130.

Lortz S, Gurgul-Convey E, Lenzen S \& Tiedge M 2005 Importance of mitochondrial superoxide dismutase expression in insulin-producing cells for the toxicity of reactive oxygen species and proinflammatory cytokines. Diabetologia 48 1541-1548.

Lubberts E, Joosten LA, van de Loo FA, van den Gersselaar LA \& van den Berg WB 2000 Reduction of interleukin-17-induced inhibition of chondrocyte proteoglycan synthesis in intact murine articular cartilage by interleukin-4. Arthritis and Rheumatism 43 1300-1306.

Mandrup-Poulsen T 1996 The role of interleukin-1 in the pathogenesis of IDDM. Diabetologia 39 1005-1029.

Mandrup-Poulsen T 2003a Apoptotic signal transduction pathways in diabetes. Biochemical Pharmacology 66 1433-1440.

Mandrup-Poulsen T $2003 \mathrm{~b}$ Beta cell death and protection. Annals of the New York Academy of Sciences 1005 32-42. 
Mandrup-Poulsen T, Bendtzen K, Dinarello CA \& Nerup J 1987 Human tumor necrosis factor potentiates human interleukin 1-mediated rat pancreatic beta-cell cytotoxicity. Journal of Immunology 139 4077-4082.

Mandrup-Poulsen T, Helqvist S, Wogensen LD, Molvig J, Pociot F, Johannesen J \& Nerup J 1990 Cytokine and free radicals as effector molecules in the destruction of pancreatic beta cells. Current Topics in Microbiology and Immunology 164 169-193.

Molina-Holgado E, Arevalo-Martin A, Castrillo A, Bosca L, Vela JM \& Guaza C 2002 Interleukin-4 and interleukin-10 modulate nuclear factor kappaB activity and nitric oxide synthase-2 expression in Theiler's virus-infected brain astrocytes. Journal of Neurochemistry $\mathbf{8 1}$ 1242-1252.

Mosmann T 1983 Rapid colorimetric assay for cellular growth and survival: application to proliferation and cytotoxicity assays. Journal of Immunological Methods 65 55-63.

Nelson G, Wilde GJ, Spiller DG, Kennedy SM, Ray DW, Sullivan E, Unitt JF \& White MR 2003 NF-KB signalling is inhibited by glucocorticoid receptor and STAT6 via distinct mechanisms. Journal of Cell Science $\mathbf{1 1 6}$ 2495-2503

Nerup J, Mandrup-Poulsen T, Helqvist S, Andersen HU, Pociot F, Reimers JI, Cuartero BG, Karlsen AE, Bjerre U \& Lorenzen T 1994 On the pathogenesis of IDDM. Diabetologia 37 S82-S89.

Nishisaka F, Sohen S, Fukuoka H, Okamoto Y, Matukawa M, Fukuda K \& Hamanishi C 2001 Interleukin-4 reversed the interleukin-1inhibited proteoglycan synthesis through the inhibition of NO release: a possible involvement of intracellular calcium ion. Pathophysiology 7 289-293.

Ohmori Y \& Hamilton TA 2000 Interleukin-4/STAT6 represses STAT1 and NF-kappa B-dependent transcription through distinct mechanisms. Journal of Biological Chemistry 275 38095-38103.

Paintlia AS, Paintlia MK, Singh I \& Singh AK 2006 IL-4-induced peroxisome proliferator-activated receptor gamma activation inhibits NF-kappaB trans activation in central nervous system (CNS) glial cells and protects oligodendrocyte progenitors under neuroinflammatory disease conditions: implication for CNS-demyelinating diseases. Journal of Immunology 176 4385-4398.

Pennline KJ, Roque-Gaffney E \& Monahan M 1994 Recombinant human IL-10 prevents the onset of diabetes in the nonobese diabetic mouse. Clinical Immunology and Immunopathology 71 169-175.

Pennock JL \& Grencis RK 2006 The mast cell and gut nematodes: damage and defence. Chemical Immunology and Allergy 90 128-140.

Perretti M, Szabo C \& Thiemermann C 1995 Effect of interleukin-4 and interleukin-10 on leucocyte migration and nitric oxide production in the mouse. British Journal of Pharmacology 116 2251-2257.

Plunkett JA, Yu CG, Easton JM, Bethea JR \& Yezierski RP 2001 Effects of interleukin-10 (IL-10) on pain behavior and gene expression following excitotoxic spinal cord injury in the rat. Experimental Neurology 168 144-154.

Qadri I, Iwahashi M, Capasso JM, Hopken MW, Flores S, Schaack J \& Simon FR 2004 Induced oxidative stress and activated expression of manganese superoxide dismutase during hepatitis $\mathrm{C}$ virus replication: role of JNK, $\mathrm{p} 38$ MAPK and AP-1. Biochemical Journal 378 919-928.

Rabinovitch A \& Suarez-Pinzon WL 2003 Role of cytokines in the pathogenesis of autoimmune diabetes mellitus. Reviews in Endocrine and Metabolic Disorders 4 291-299.

Racke MK, Bonomo A, Scott DE, Cannella B, Levine A, Raine CS, Shevach EM \& Rocken M 1994 Cytokine-induced immune deviation as a therapy for inflammatory autoimmune disease. Journal of Experimental Medicine $\mathbf{1 8 0}$ 1961-1966.

Rapoport MJ, Jaramillo A, Zipris D, Lazarus AH, Serreze DV, Leiter EH, Cyopick P, Danska JS \& Delovitch TL 1993 Interleukin 4 reverses $T$ cell proliferative unresponsiveness and prevents the onset of diabetes in nonobese diabetic mice. Journal of Experimental Medicine 178 87-99.

Raz I, Eldor R \& Naparstek Y 2005 Immune modulation for prevention of type 1 diabetes mellitus. Trends in Biotechnology 23 128-134.

Ronn SG, Billestrup N \& Mandrup-Poulsen T 2007 Diabetes and suppressors of cytokine signaling proteins. Diabetes 56 541-548.
Saldeen J 2000 Cytokines induce both necrosis and apoptosis via a common Bcl-2-inhibitable pathway in rat insulin-producing cells. Endocrinology 141 2003-2010.

Sandler S \& Sternesjo J 1995 Interleukin 4 impairs rat pancreatic islet function in vitro by an action different to that of interleukin 1. Cytokine 7 296-300.

Sandler S, Eizirik DL, Svensson C, Strandell E, Welsh M \& Welsh N 1992 Are cytokines mediators in the development of insulin-dependent diabetes mellitus? Lakartidningen 89 1777-1779.

Serafin A, Rosello-Catafau J, Prats N, Gelpi E, Rodes J \& Peralta C 2004 Ischemic preconditioning affects interleukin release in fatty livers of rats undergoing ischemia/reperfusion. Hepatology 39 688-698.

Storling J, Binzer J, Andersson AK, Zullig RA, Tonnesen M, Lehmann R, Spinas GA, Sandler S, Billestrup N \& Mandrup-Poulsen T 2005 Nitric oxide contributes to cytokine-induced apoptosis in pancreatic beta cells via potentiation of JNK activity and inhibition of Akt. Diabetologia $\mathbf{4 8}$ 2039-2050.

Suarez-Pinzon WL, Mabley JG, Strynadka K, Power RF, Szabo C \& Rabinovitch A 2001 An inhibitor of inducible nitric oxide synthase and scavenger of peroxynitrite prevents diabetes development in NOD mice. Journal of Autoimmunity 16 449-455.

Tiedge M, Lortz S, Drinkgern J \& Lenzen S 1997 Relation between antioxidant enzyme gene expression and antioxidative defense status of insulin-producing cells. Diabetes 46 1733-1742.

Tiedge M, Lortz S, Munday R \& Lenzen S 1999 Protection against the co-operative toxicity of nitric oxide and oxygen free radicals by overexpression of antioxidant enzymes in bioengineered insulin-producing RINm5F cells. Diabetologia 42 849-855.

Todaro M, Di Gaudio F, Lavitrano M, Stassi G \& Papaccio G 2003 Islet beta-cell apoptosis triggered in vivo by interleukin- $1 \beta$ is not related to the inducible nitric oxide synthase pathway: evidence for mitochondrial function impairment and lipoperoxidation. Endocrinology 144 4264-4271.

Veluthakal R, Amin R \& Kowluru A 2004 Interleukin-1 beta induces posttranslational carboxymethylation and alterations in subnuclear distribution of lamin B in insulin-secreting RINm5F cells. American Journal of Physiology. Cell Physiology 287 C1152-C1162.

Verri WA Jr, Cunha TM, Parada CA, Poole S, Cunha FQ \& Ferreira SH 2006 Hypernociceptive role of cytokines and chemokines: targets for analgesic drug development? Pharmacology and Therapeutics $\mathbf{1 1 2}$ $116-138$.

Walsh GM 2006 Targeting airway inflammation: novel therapies for the treatment of asthma. Current Medicinal Chemistry 13 3105-3111.

Wright K, Kolios G, Westwick J \& Ward SG 1999 Cytokine-induced apoptosis in epithelial HT-29 cells is independent of nitric oxide formation. Evidence for an interleukin-13-driven phosphatidylinositol 3-kinase-dependent survival mechanism. Journal of Biological Chemistry 274 17193-17201.

Zaccone P, Phillips J, Conget I, Gomis R, Haskins K, Minty A, Bendtzen K, Cooke A \& Nicoletti F 1999 Interleukin-13 prevents autoimmune diabetes in NOD mice. Diabetes 48 1522-1528.

Zaitseva II, Sharoyko V, Storling J, Efendic S, Guerin C, Mandrup-Poulsen T, Nicotera P, Berggren PO \& Zaitsev SV 2006 RX871024 reduces NO production but does not protect against pancreatic beta-cell death induced by proinflammatory cytokines. Biochemical and Biophysical Research Communications 347 1121-1128.

Zumsteg U, Frigerio S \& Hollander GA 2000 Nitric oxide production and Fas surface expression mediate two independent pathways of cytokine-induced murine beta-cell damage. Diabetes 49 39-47.

\section{Received in final form 20 December 2007 \\ Accepted 4 February 2008 \\ Made available online as an Accepted Preprint 5 February 2008}

